\title{
PERAN MANAJEMEN SUMBER DAYA MANUSIA DALAM LEMBAGA PENDIDIKAN
}

\author{
Oleh: Fahmiah Akilah \\ Dosen IAIN Bone
}

\begin{abstract}
One of the most critical resources in management is human resources. The importance of this human resource requires being apprehended by all levels of management, as well as in management education. Although the emergence of sophisticated technology today, the human factor still strikes an essential role in the success of an association. Human resources are an indispensable constituent in an organisation because humans are the first and primary element in management before the other aspects. Accordingly, human resource management has a vital role in administering and accomplishing organizational goals, not least in educational institutions. Human resources must be appropriately regulated by its function so that these human resources can execute a role in the duties and functions of the institutions that they involve.
\end{abstract}

Keywords: Human Resources, Educational Institution

\section{A. Pendahuluan}

Manusia sebagai makhluk ciptaan Tuhan Yang Maha Esa memiliki berbagai potensi termasuk potensi untuk berkelompok dalam sebuah ikatan yang bertujuan dan bekerja sama untuk mencapai tujuan. Manusia sebagai ciptaan Allah swt. tidak dapat ditelaah hanya sebagai fenomena alam semata-mata, dan juga sebagai makhluk yang berakar juga tidak dapat ditelaah hanya sebagai fenomena budaya. Dalam diri manusia selaku makhluk melekat fenomena alam dan juga fenomena budaya yang menjadi keunikan manusia. Sebagai individu, manusia merupakan kesatuan jasmani dan rohani yang mencirikan otonomi dirinya bahwa bayi sejak lahir sampai usia tertentu merupakan individu yang tidak berdaya. Tanpa bantuan orang di sekitarnya, manusia tidak dapat berbuat apa-apa. 
Manusia hidup dilahirkan dalam organisasi, dididik oleh organisasi, dan hampir dari semua manusia mempergunakan waktu hidupnya bekerja untuk organisasi. Waktu senggangnya digunakan untuk bermain-main, berdoa, beristirahat, di dalam organisasi. Demikian pula manusia bakal mati di dalam suatu organisasi dan ketika sampai ke pemakaman, organisasi masih tetap memegang peranan. ${ }^{1}$ Ungkapan tersebut menandakan dengan jelas bahwa manusia dan organisasi menandakan bahwa manusia dan organisasi sudah menyatu karena organisasi tidak akan berjalan tanpa manusia.

Salah satu sumber daya yang penting dalam manajemen adalah sumber daya manusia atau human resource. Pentingnya sumber daya manusia ini perlu disadari oleh semua tingkatan manajemen, termasuk juga dalam manajemen pendidikan Islam. Bagaimanapun majunya teknologi saat ini, namun faktor manusia tetap memegang peranan penting bagi keberhasilan suatu organisasi. Bahkan dapat dikatakan bahwa manajemen itu pada hakikatnya adalah manajemen sumber daya manusia, atau manajemen sumber daya manusia adalah identik dengan manajemen itu sendiri.

Setiap organisasi pada umumnya sangat memerlukan adanya sumber daya manusia karena bagi organisasi, sumber daya manusia merupakan asset paling berharga yang dimilikinya. Menurut Nurul Ulfatin dan Teguh Priyanto sumber daya manusia merupakan pekerja, pegawai, karyawan, atau orang-orang yang mengerjakan atau mempunyai pekerjaan. ${ }^{2}$ Dari pengertian tersebut dapat diketahui bahwa sumber daya manusia dalam organisasi merupakan tenaga kerja yang menduduki suatu posisi atau orang-

\footnotetext{
${ }^{1}$ Abdul Aziz Wahab, Anatomi Organisasi dan Kepemimpinan Pendidikan: Telaah terhadap Organisasi dan Pengelolaan Organisasi Pendidikan (Cet. II; Bandung: Alfabeta, 2011), h. 175.

${ }^{2}$ Nurul Ulfatin dan Teguh Triwiyanto, Manajemen Sumber Daya Manusia Bidang Pendidikan (Cet. I; Jakarta, RajaGrafindo Persada, 2016), h. 2.
} 
orang yang mempunyai tanggung jawab untuk melaksanakan tugas atau pekerjaan pada suatu organisasi tertentu.

Dalam lembaga pendidikan manajemen sumber daya manusia adalah hal yang sangat penting untuk diterapkan. Tanpa manajemen sumber daya manusia, suatu organisasi pada umumnya akan kesulitan dalam mencapai tujuannya, begitu pula dalam lembaga pendidikan. Manajemen sumber daya manusia merupakan unsur terpenting dalam manajemen karena sumber daya manusia merupakan unsur pertama dalam manajemen sebelum unsur-unsur lainnya. Peranan manajemen sumber daya manusia dalam lembaga pendidikan tentu sangat berkontribusi dalam membantu meningkatkan mutu pendidikan, karena pendidikan yang bermutu berasal dari orang-orang yang mengelola pendidikan itu sendiri adalah sumber daya manusia yang bermutu pula.

\section{B. Pengertian dan Pentingnya Manajemen Sumber Daya Manusia}

Berbagai istilah yang sering digunakan untuk menunjukkan manajemen sumber daya manusia, seperti manajemen sumber daya insani, manajemen personalia, manajemen kepegawaian, manajemen perburuhan, manajemen tenaga kerja, administrasi personalia (kepegawaian), dan hubungan industrial.

Pergantian istilah dari manajemen personalia kepada manajemen sumber daya manusia dianggap sebagai suatu gerakan yang mencerminkan pengakuan adanya peranan vital dan menunjukkan pentingnya sumber daya manusia dalam suatu organisasi. Adanya tantangan-tantangan yang semakin besar dalam pengelolaan sumber daya manusia secara efektif, serta terjadinya pertumbuhan ilmu pengetahuan dan profesionalisme di bidang manajemen sumber daya manusia. 
Manajemen sumber daya manusia merupakan salah satu bidang dari manajemen umum yang meliputi segi-segi perencanaan, pengorganisasian, pelaksanaan, dan pengendalian. Sumber daya manusia dianggap semakin penting karena dalam pencapaian tujuan organisasi, maka berbagai pengalaman dan hasil penelitian dalam bidang sumber daya manusia dikumpulkan secara sistematis dengan apa yang disebut dengan manajemen sumber daya manusia. Istilah management mempunyai arti sebagai kumpulan pengetahuan tentang bagaimana seharusnya memanage (mengelola) sumber daya manusia. ${ }^{3}$

Menurut Hall T. Douglas dan Goodale G. James manajemen sumber daya manusia adalah "the process through which optimal fit is achieved among the employee, job organization, and environment so that employees reach their desired level of satisfaction and performance and the organization meets it's goals"4 (manajemen sumber daya manusia adalah suatu proses melalui kesesuaian optimal yang diperoleh di antara pegawai, pekerjaan organisasi, dan lingkungan sehingga para pegawai mencapai tingkat kepuasan dan performansi yang mereka inginkan dan organisasi memenuhi tujuannya.

Edwin B. Flippo mengemukakan definisi manajemen personalia sebagai "Personal management is the planning, organizing, directing and controlling of the procurement, development, compensation, integration, maintenance, and separation of human resources to the that individual, organizational and societal objectives are accomplished. (Manajemen personalia adalah perencanaan, pengorganisasian, pengarahan, dan pengendalian, pengembangan, kompensasi, pengintegrasian, pemeliharaan,

\footnotetext{
${ }^{3}$ Veithzal Rivai dkk., Manajemen Sumber Daya Manusia untuk Perusahaan: dari Teori ke Praktek (Cet. I; Jakarta: RajaGafindo Persada, 2004), h.1.

${ }^{4}$ Hall T. Douglas \& James Goodale G, Human Resources Management, Strategy, Design and Implementation (Glenview: Scoot Foresman and Company, 1986), h. 6.
} 
dan pemberhentian karyawan, dengan maksud terwujudnya tujuan perusahaan, individu, karyawan, dan masyarakat). ${ }^{5}$ Lebih lanjut, Hasibuan mendefinisikan manajemen sumber daya manusia sebagai ilmu dan seni mengatur hubungan dan peranan tenaga kerja agar efektif dan efisien membantu terwujudnya tujuan organisasi, karyawan, dan masyarakat. ${ }^{6}$

Pembahasan mengenai manajemen sumber daya manusia adalah bahwa manusia merupakan unsur terpenting dalam semua organisasi, keberhasilan organisasi dalam mencapai tujuan dan berbagai sasarannya serta kemampuannya menghadapi berbagai tantangan, baik yang bersifat eksternal maupun yang bersifat internal sangat ditentukan oleh kemampuan mengelola sumber daya manusia dengan setepat-tepatnya. Masalah-masalah pengembangan diri, keadilan, kewajaran, harapan dan kecocokan pekerjaan dengan karakteristik seseorang, masalah-masalah perilaku organisasi merupakan bagian dari pengelolaan sumber daya manusia yang penting. ${ }^{7}$

Dalam lembaga pendidikan, manajemen sumber daya manusia adalah segala kegiatan yang berkaitan dengan pengakuan pada pentingnya tenaga pendidik dan tenaga kependidikan pada sekolah sebagai sumber daya manusia yang vital, yang memberikan kontribusi atau sumbangsih terhadap tujuan sekolah, dan memanfaatkan fungsi dan kegiatan yang menjamin bahwa sumber daya manusia dimanfaatkan secara efektif dan atau demi kemaslahatan individu, sekolah dan masyarakat. ${ }^{8}$ Berdasarkan pengertian tersebut, Astuti memandang bahwa posisi sumber daya manusia tidak bisa

\footnotetext{
${ }^{5}$ Malayu S.P. Hasibuan, Manajemen Sumber Daya Manusia: Dasar dan Kunci Keberhasilan (Cet. I; Jakarta: Haji Masagung, 1990), h. 11.

${ }^{6}$ Malayu S.P Hasibuan, Manajemen Sumber Daya Manusia (Cet. XX; Jakarta: Bumi Aksara, 2016), h. 10.

${ }^{7}$ Sondang P. Siagian, Manajemen Sumber Daya Manusia (Cet. XXI; Jakarta: Bumi Aksara, 2014), h. 40.

${ }^{8}$ Departemen Pendidikan Nasional. Manajemen Pemberdayaan Sumber Daya Tenaga Pendidik dan Kependidikan Sekolah, (2008), h. 12.
} 
digantikan oleh faktor-faktor lain dilihat dari nilai sumbangannya terhadap sekolah. Seorang tenaga pendidik dan kependidikan dinyatakan memiliki nilai sumbangan kepada sekolah apabila kehadirannya diperlukan, memiliki nilai tambah terhadap produktivitas sekolah, dan kegiatannya berada dalam mata rantai kebutuhan sistem sekolah itu. ${ }^{9}$

Berdasarkan pengertian-pengertian manajemen sumber daya manusia tersebut, dapat diketahui bahwa manajemen sumber daya manusia pada hakikatnya adalah aktivitas untuk mencapai keberhasilan organisasi mencapai tujuan dan berbagai sasarannya serta kemampuan menghadapi tantangan melalui kebijakan-kebijakan, praktik-praktik, serta sistem-sistem yang mempengaruhi perilaku, sikap, dan kinerja pegawai yang berada dalam organisasi.

\section{Tujuan dan Ruang Lingkup Manajemen Sumber Daya Manusia}

Setiap organisasi menetapkan tujuan-tujuan tertentu yang ingin mereka capai dalam mengatur sumber dayanya termasuk sumber daya manusia. Tujuan manajemen sumber daya manusia secara tepat sangatlah sulit untuk dirumuskan karena sifatnya bervariasi dan tergantung pada penahapan perkembangan yang terjadi pada masing-masing organisasi. ${ }^{10}$

Untuk mencapai kebermaknaan sumber daya manusia yang optimal, maka diperlukan manajemen dengan tujuan yang jelas. Tujuan manajemen dapat dilihat dari tingkat yang paling rendah, yaitu tingkat personal (personal objective), naik ke tingkat yang lebih tinggi, yaitu tujuan fungsional (function objective), dilanjutkan ke tujuan organisasional

\footnotetext{
${ }^{9}$ Astuti, Manajemen Pendidikan (Cet. I; Samata-Gowa: Gunadarma Ilmu, 2016), h. 18.

${ }^{10}$ Edy Sutrisno, Manajemen Sumber Daya Manusia (Cet. VI; Jakarta: Kencana, 2014), h. 5.
} 
(organizational objective), dan puncaknya untuk tujuan layanan masyarakat secara nasional dan internasional (society objective). ${ }^{11}$

\section{Tujuan Personal (Personal Objective)}

Tujuan personal yaitu membantu sumber daya manusia untuk mencapai tujuan diri individunya. Tujuan individual ini berentang dari yang sangat teknis sampai dengan yang aspirasi, dan dari tujuan jangka pendek sampai dengan jangka panjang. Tujuan yang bersifat teknis, setiap individu tercermin dari kegiatan riil dan kontribusi dirinya dalam organisasi, sedangkan tujuan aspirasi tercermin pada motivasi dan kepuasannya dalam organisasi. Tujuan jangka pendek individu umumnya untuk mencapai pemenuhan kebutuhan dasar seperti makan, minum, dan sandang, sampai dengan kebutuhan tingkat tinggi yaitu aktualisasi diri (lihat teori Maslow). Sedangkan kebutuhan jangka panjang merupakan kebutuhan rohani untuk mencapai tujuan di akhirat nanti. Kebutuhan jangka panjang ini tercermin dari keyakinannya bahwa pencapaian tujuan duniawi (terutama bekerja) merupakan alat untuk memenuhi kebutuhan rohani di akhirat nanti.

Pada diri pendidik tujuan personal dapat ditunjukkan bahwa ia bekerja untuk mencari nafkah untuk memenuhi kebutuhan keluarga. Namun, secara jangka panjang, ia bekerja di bidang pendidikan karena dilandasi oleh motivasi yang didorong suatu keyakinan bahwa sebagai seorang pendidik merupakan panggilan hidup yang semata-mata untuk mengamalkan ilmu untuk mengantarkan generasi lebih baik, dan yang demikian ini akan mendapatkan pahala yang tidak akan putus sampai di akhirat nanti.

Berdasarkan uraian di atas, tujuan manajemen sumber daya manusia secara personal adalah memberikan peluang yang sama kepada setiap personel untuk mencapai tujuan pribadinya. Di samping itu, tujuan

\footnotetext{
${ }^{11}$ Nurul Ulfatin dan Teguh Triwiyanto, Manajemen Sumber Daya Manusia, h. 11.
} 
manajemen juga harus memelihara dan memberi kesempatan munculnya motivasi pribadi untuk meningkatkan produktivitas organisasi.

\section{Tujuan Fungsional (Functional Objective)}

Tujuan fungsional manajemen sumber daya manusia adalah tujuan yang memelihara kontribusi bagian-bagian dalam organisasi agar sumber daya manusia pada bagian-bagian itu dapat menjalankan tugas secara optimal. Setiap sumber daya manusia akan memiliki makna fungsional jika manajemennya mampu memenuhi tujuan permintaan organisasi. Dengan demikian manajemen bertugas untuk mengoptimalkan agar setiap sumber daya manusia dapat berkontribusi pada bagian tugas dan fungsi yang dijalankan.

Tujuan fungsional manajemen sumber daya manusia adalah menjaga agar guru tidak terlambat di kelas dan guru dapat membuat persiapan secara baik. Dengan kata lain, tujuan fungsional adalah memelihara dan memfasilitasi agar guru dapat menjalankan tugasnya secara optimal sesuai tugas dan fungsinya.

\section{Tujuan Organisasional (Organizational Objective)}

Tujuan organisasional manajemen sumber daya manusia adalah tujuan yang terkait dengan keefektifan organisasi. Tujuan organisasional ini tercermin dari pencapaian kinerja dan produktivitas organisasi. Jika organisasi itu sekolah, tujuan organisasionalnya adalah tingkat dan kualitas lulusan sekolah. Tingkat dan kualitas lulusan sekolah sangat tergantung pada kinerja dan produktivitas pada pendidik dan tenaga kependidikan yang ada di sekolah, di samping juga tergantung kepada sumber-sumber yang lain. Sebagai contoh tujuan organisasional para pendidik dan tenaga kependidikan adalah melayani dan mengoptimalkan bagian-bagian dalam organisasi (misalnya manajemen peserta didik) untuk mencapai tujuan sekolah. 


\section{Tujuan Masyarakat (Society Objective)}

Tujuan masyarakat adalah untuk memenuhi kebutuhan dan tantangan yang timbul di masyarakat, sehingga organisasi diharapkan dapat memberi manfaat atau keuntungan bagi masyarakat. Pencapaian tujuan masyarakat merupakan dampak (outcomes) yang ditimbulkan dari pencapaian tujuan sebelumnya, yaitu tujuan organisasional. Pencapaian tujuan masyarakat pendidikan tercermin dari keberhasilan generasi yang dihasilkan oleh sekolah sebagai warga masyarakat yang jauh lebih berkualitas dari masyarakat pada generasi sebelumnya.

Tujuan manajemen sumber daya manusia pendidikan sebagaimana di kemukakan di atas menunjukkan bahwa tujuan itu berbeda dengan tujuan manajemen sumber daya manusia pada bidang lain seperti di perusahaan atau pabrik. Tujuan manajemen sumber daya manusia pada perusahaan atau pabrik lebih banyak untuk mencapai tujuan organisasional, yaitu dihasilkannya produksi yang tinggi untuk mendapat keuntungan finansial (profit).

Adanya perbedaan orientasi tujuan manajemen sumber daya manusia akan berdampak pada kegiatan yang dijalankan di bidang pendidikan. Tujuan manajemen sumber daya manusia di bidang pendidikan sebagaimana yang dikemukakan oleh Astuti dalam Departemen Pendidikan Nasional menyatakan bahwa manajemen sumber daya manusia bertujuan untuk memenuhi kebutuhan tenaga pendidik dan kependidikan, mengembangkan dan memberdayakan tenaga pendidik dan kependidikan untuk memperoleh nilai maslahat optimal bagi individu tenaga pendidik dan kependidikan yang bersangkutan, sekolah dan masyarakat yang dilayaninya. ${ }^{12}$

\footnotetext{
${ }^{12}$ Astuti, Manajemen Pendidikan, h. 20.
} 
Lebih lanjut E. Mulyasa dalam Mujamil Qamar mengemukakan bahwa manajemen personalia atau tenaga kependidikan bertujuan untuk mendayagunakan tenaga kependidikan secara efektif dan efisien guna mencapai hasil yang optimal, namun tetap dalam kondisi yang menyenangkan. ${ }^{13}$ Manajemen sumber daya manusia dilaksanakan untuk mewujudkan sekolah yang sehat, yaitu sekolah yang memiliki jumlah dan kualifikasi tenaga pendidik dan kependidikan sesuai dengan beban dan tugas-tugas sekolah yang ada di dalamnya. Manajemen sumber daya manusia harus mendukung tingkat ketahanan sekolah, pertumbuhan, produktivitas dan kompetisi.

Berdasarkan beberapa uraian tersebut dapat diketahui bahwa tujuan manajemen sumber daya manusia pendidikan adalah pencapaian kinerja pendidik dan tenaga kependidikan, menciptakan kondisi kerja yang harmonis tanpa mengorbankan unsur-unsur manusia yang terlibat dalam kegiatan pendidikan. Manajemen sumber daya manusia dilakukan agar tenaga pendidik dan kependidikan dapat melaksanakan tugasnya dengan baik sehingga dapat mencapai tujuan individu, tujuan fungsional, tujuan organisasi, dan tujuan masyarakat.

Ruang lingkup manajemen sumber daya manusia dalam pendidikan mencakup hal-hal sebagai berikut: ${ }^{14}$

1. Perencanaan sumber daya manusia

2. Analisis tenaga pendidik dan tenaga kependidikan

3. Pengadaan tenaga pendidik dan tenaga kependidikan

4. Seleksi tenaga pendidik dan tenaga kependidikan

5. Orientasi, penempatan, dan penugasan

\footnotetext{
${ }^{13}$ Mujamil Qamar, Manajemen Pendidikan Islam: Strategi Baru Pengelolaan Lembaga Pendidikan Islam (Erlangga, 2009), h. 130.

${ }^{14}$ Mujamil Qamar, Manajemen Pendidikan Islam, h. 17.
} 
6. Kompensasi

7. Penilaian kinerja

8. Pengembangan karir

9. Pelatihan dan pengembangan tenaga pendidik dan tenaga kependidikan

10. Penciptaan mutu kehidupan kerja

11. Perundingan tenaga pendidik dan tenaga kependidikan

12. Riset tenaga pendidik dan tenaga kependidikan

13. Pensiun dan pemberhentian tenaga pendidik dan tenaga kependidikan.

\section{Peran Manajemen Sumber Daya Manusia}

Manajemen sumber daya manusia dewasa ini mendapat sorotan tajam dari berbagai pihak. Sumber daya manusia mempunyai dampak yang lebih besar terhadap efektivitas organisasi dibanding dengan sumber daya yang lain. Seberapa baik sumber daya manusia dikelola akan semakin menentukan kesuksesan organisasi di masa mendatang. Pengelolaan sumber daya manusia sendiri akan menjadi bagian yang sangat penting dari tugas manajemen organisasi. Sebaliknya, jika sumber daya manusia tidak dikelola dengan baik maka efektivitas tidak akan tercapai.

Manajemen sumber daya manusia menganggap bahwa karyawan adalah kekayaan utama yang dimiliki organisasi yang harus dikelola dengan baik. Oleh karena itu, manajemen sumber daya manusia sifatnya lebih strategis bagi organisasi dalam mencapai tujuan-tujuan yang telah ditetapkan. ${ }^{15}$ Sebuah organisasi dalam mewujudkan eksistensinya dalam rangka mencapai tujuan memerlukan perencanaan sumber daya manusia

\footnotetext{
${ }^{15}$ Yusmiar, Manajemen Sumber Daya Manusia dalam Peningkatan Kinerja Pegawai (Cet. I; Samata-Gowa: Alauddin University Press, 2014), h. 51.
} 
yang efektif. Suatu organisasi menurut Rivai bahwa tanpa didukung pegawai/karyawan yang sesuai, baik dari segi kuantitatif, kualitatif, strategi dan operasionalnya, maka organisasi/perusahaan itu tidak akan mampu mempertahankan keberadaannya, mengembangkan dan memajukan organisasi di masa yang akan datang. ${ }^{16}$

Sebagai faktor pertama dan utama dalam proses pembangunan, sumber daya manusia selalu menjadi subjek dan objek pembangunan. Proses administrasi pun sangat dipengaruhi oleh manajemen sumber daya manusia. Menurut Ermayana dalam Fathoni mengemukakan klasifikasi sumber daya manusia, yaitu: ${ }^{17}$

1. Manusia atau orang-orang yang mempunyai kewenangan untuk menetapkan, mengendalikan, dan mengarahkan pencapaian tujuan disebut administrator.

2. Manusia atau orang-orang yang mengendalikan dan memimpin usaha agar proses pencapaian tujuan yang dilaksanakan bisa tercapai sesuai dengan rencana, disebut manajer.

3. Manusia atau orang-orang yang memenuhi syarat tertentu, diangkat langsung mengerjakan pekerjaan sesuai dengan bidang tugasnya masing-masing atau jabatan yang dipegangnya.

Meningkatnya peran manajemen sumber daya manusia disebabkan oleh keyakinan organisasi akan perannya yang strategis demi kesuksesan kompetitif organisasi. Keunggulan kompetitif sangat bergantung pada inovasi. Inovasi sendiri dipengaruhi oleh faktor motivasi dan moral kerja pegawai atau karyawan. Sikap pegawai atau karyawan merupakan hasil pembentukan kebijakan dan praktik lingkungan manajemen sehingga peran

\footnotetext{
${ }^{16}$ Veithzal Rivai dkk., Manajemen Sumber Daya Manusia untuk Perusahaan, h. 35.

${ }^{17}$ Abdurrahmat Fathoni, Manajemen Sumber Daya Manusia (Cet. I; Jakarta: Rineka Cipta, 2009), h. 12.
} 
utama khususnya sumber daya manusia adalah membantu organisasi dalam memenuhi misi, visi, tujuan dan struktur organisasi.

Karena pentingnya peran sumber daya manusia dalam pelaksanaan dan pencapaian tujuan organisasi maka pengelolaan sumber daya manusia harus memperhatikan beberapa aspek, seperti aspek staffing, pelatihan dan pengembangan, motivasi dan pemeliharaannya yang secara lebih mendetail dikemukakan oleh De Cenzo and Robbins dalam Yusmiar menyatakan bahwa "human resources management is the part of the organization that is concerned with the people or human resources aspect of management position, including recruiting, screening, training, rewarding, and appraising". 18

Peran manajemen sumber daya manusia sebagai faktor sentral dalam organisasi dapat dikelompokkan menjadi beberapa peran, di antaranya adalah sebagai berikut: ${ }^{19}$

1. Peran Administrasi Manajemen Sumber Daya Manusia

Peran ini difokuskan pada pemrosesan dan penyimpanan data, meliputi penyimpanan database dan arsip pegawai, proses klaim keuntungan, kebijakan organisasi tentang program pemeliharaan dan kesejahteraan pegawai, pengumpulan dokumen, dan sebagainya. Namun, hal ini menimbulkan anggapan bahwa sumber daya manusia hanya sebagai alat pengumpul kertas atau dokumen saja. Jika peran administrasi hanya seperti ini, sumber daya manusia hanya dipandang dari dimensi klerikal dan kontributor administrasi hierarki bawah pada organisasi.

\footnotetext{
${ }^{18}$ Yusmiar, Manajemen Sumber Daya Manusia dalam Peningkatan Kinerja Pegawai, h. 54-55.

${ }^{19}$ Ike Kusdyah Rachmawati, Manajemen Sumber Daya Manusia (Edisi I; Yogyakarta: Andi Offest, 2008), h. 7.
} 
Peran administrasi pada beberapa organisasi dilakukan oleh pihak ketiga di luar organisasi (outsourcing) daripada dilakukan sendiri oleh organisasi. Bahkan teknologi semakin berperan dan dilibatkan dalam mengotomatisasikan pekerjaan yang bersifat administratif.

2. Peran Operasional Manajemen Sumber Daya Manusia

Peran ini lebih bersifat taktis, meliputi pemrosesan lamaran pekerjaan, proses seleksi dan wawancara, kepatuhan terhadap kebijakan dan peraturan, peluang bekerja dengan kondisi baik, pelatihan dan pengembangan, program $\mathrm{K} 3$, dan sistem kompensasi. Banyak aktivitas yang harus dilakukan dan melibatkan koordinasi dengan para manajer dan supervisor di semua jenjang organisasi. Penekanan pada operasional masih banyak terjadi di beberapa organisasi sebab keterbatasan kemampuan individu dan penolakan manajemen puncak terhadap peran sumber daya manusia yang semakin besar.

\section{Peran Strategis Manajemen Sumber Daya Manusia}

Keunggulan kompetitif dari unsur sumber daya manusia merupakan kelebihan yang dimiliki oleh peran ini. Peran strategis ini menekankan bahwa orang-orang dalam organisasi merupakan sumber daya yang penting dan investasi organisasi yang besar. Agar sumber daya manusia dapat berperan strategis maka harus fokus pada masalah-masalah dan implikasi sumber daya manusia jangka panjang. Bagaimana perubahan kependudukan tenaga kerja dan kekurangan tenaga kerja akan memengaruhi organisasi dan cara apa yang akan digunakan untuk menyiasati masalah kekurangan tersebut.

Sebagaimana telah dikemukakan sebelumnya bahwa manajemen sumber daya manusia sangat diperlukan bagi suatu organisasi, instansi maupun perusahaan dalam pengelolaan tenaga kerja atau karyawan. Oleh 
karena itu, organisasi atau perusahaan tidak mungkin tidak menerapkannya, karena manajemen sumber daya memiliki peranan yang sangat vital, yaitu:

1. Menetapkan jumlah, kualitas dan penempatan tenaga kerja yang sesuai dengan kebutuhan organisasi berdasarkan job description, job specification, dan job requitment.

2. Menetapkan penarikan, seleksi dan penempatan karyawan berdasarkan atas asas the right man in the right place and the right man in the right job.

3. Menetapkan program kesejahteraan, pengembangan, promosi dan pemberhentian.

4. Meramalkan penawaran dan permintaan sumber daya manusia pada masa yang akan datang.

5. Memperkirakan keadaan perekonomian pada umumnya dan perkembangan organisasi kita pada khususnya.

6. Memonitor dengan cermat Undang-Undang perburuhan dan kebijaksanaan pemberian balas jasa organisasi-organisasi sejenis.

7. Memonitor kemajuan teknik dan perkembangan serikat buruh.

8. Melaksanakan pendidikan, latihan, dan penilaian prestasi kerja pegawai.

9. Mengatur mutasi pegawai baik vertikal maupun horizontal.

10. Mengatur pensiunan, pemberhentian dan pesangonnya. ${ }^{20}$

Berdasarkan uraian di atas dapat diketahui bahwa peranan sumber daya manusia sangat esensial dalam menjalankan suatu organisasi karena manusia adalah kunci dari semua persoalan. Meskipun peranan manajemen sumber daya manusia yang dijelaskan sebelumnya berada dalam lingkup perusahaan atau organisasi pada umumnya, namun hal tersebut juga berlaku

\footnotetext{
${ }^{20}$ Malayu S.P. Hasibuan, Manajemen Sumber Daya Manusia, h.15.
} 
dalam lembaga pendidikan. Tenaga pendidik dan kependidikan sebagai sumber daya manusia pendidikan memegang peranan strategi terutama dalam upaya membentuk watak bangsa melalui pengembangan kepribadian dan nilai-nilai yang diinginkan.

\section{E. Penutup}

Manajemen sumber daya manusia merupakan salah satu bidang dari manajemen umum yang meliputi segi-segi perencanaan, pengorganisasian, pelaksanaan, dan pengendalian. Sumber daya manusia dianggap semakin penting karena dalam pencapaian tujuan organisasi, maka berbagai pengalaman dan hasil penelitian dalam bidang sumber daya manusia dikumpulkan secara sistematis dengan apa yang disebut dengan manajemen sumber daya manusia. Istilah management mempunyai arti sebagai kumpulan pengetahuan tentang bagaimana seharusnya memanage (mengelola) sumber daya manusia.

Untuk mencapai kebermaknaan sumber daya manusia yang optimal, maka diperlukan manajemen dengan tujuan yang jelas. Tujuan manajemen dapat dilihat dari tingkat yang paling rendah, yaitu tingkat personal (personal objective), naik ke tingkat yang lebih tinggi, yaitu tujuan fungsional (function objective), dilanjutkan ke tujuan organisasional (organizational objective), dan puncaknya untuk tujuan layanan masyarakat secara nasional dan internasional (society objective).

Manajemen sumber daya manusia menganggap bahwa karyawan adalah kekayaan utama yang dimiliki organisasi yang harus dikelola dengan baik. Oleh karena itu, manajemen sumber daya manusia sifatnya lebih strategis bagi organisasi dalam mencapai tujuan-tujuan yang telah ditetapkan. Peran manajemen sumber daya manusia sebagai faktor sentral dalam organisasi dapat dikelompokkan menjadi beberapa peran, di antaranya 
peran administrasi manajemen sumber daya manusia, peran operasional manajemen sumber daya manusia, dan peran strategis manajemen sumber daya manusia.

\section{DAFTAR RUJUKAN}

Astuti. Manajemen Pendidikan. Cet. I; Samata-Gowa: Gunadarma Ilmu, 2016.

Departemen Pendidikan Nasional. Manajemen Pemberdayaan Sumber Daya Tenaga Pendidik dan Kependidikan Sekolah, 2008.

Douglas, Hall T. \& James Goodale G. Human Resources Management, Strategy, Design and Implementation. Glenview: Scoot Foresman and Company, 1986.

Fathoni, Abdurrahmat. Manajemen Sumber Daya Manusia. Cet. I; Jakarta: Rineka Cipta, 2009.

Hasibuan, Malayu S.P. Manajemen Sumber Daya Manusia. Cet. XX; Jakarta: Bumi Aksara, 2016.

Qamar, Mujamil. Manajemen Pendidikan Islam: Strategi Baru Pengelolaan Lembaga Pendidikan Islam. Erlangga, 2009.

Rachmawati, Ike Kusdyah. Manajemen Sumber Daya Manusia. Edisi I; Yogyakarta: Andi Offest, 2008.

Rivai, Veithzal dkk. Manajemen Sumber Daya Manusia untuk Perusahaan: dari Teori ke Praktek. Cet. I; Jakarta: RajaGafindo Persada, 2004.

Siagian, Sondang P. Manajemen Sumber Daya Manusia. Cet. XXI; Jakarta: Bumi Aksara, 2014.

Sutrisno, Edy. Manajemen Sumber Daya Manusia. Cet. VI; Jakarta: Kencana, 2014.

Ulfatin, Nurul dan Teguh Triwiyanto. Manajemen Sumber Daya Manusia Bidang Pendidikan. Cet. I; Jakarta, RajaGrafindo Persada, 2016.

Wahab, Abdul Aziz. Anatomi Organisasi dan Kepemimpinan Pendidikan: Telaah terhadap Organisasi dan Pengelolaan Organisasi Pendidikan. Cet. II; Bandung: Alfabeta, 2011.

Yusmiar. Manajemen Sumber Daya Manusia dalam Peningkatan Kinerja Pegawai. Cet. I; Samata-Gowa: Alauddin University Press, 2014. 